\title{
Um engenho fortaleza: terra, política e herança no rio Capim - PA, segunda metade do século XIX
}

William Gaia Farias*

\section{RESUMO}

O estudo procura reconstruir as relações entre poder político, prestígio social e patrimônio de donos de engenho de açúcar e arroz, na região do rio Capim, partindo da atuação de dois integrantes da família Chermont de Miranda nas querelas políticas. Com o objetivo de compreender o exercício do poder dos proprietários de engenhos, a pesquisa também procurou reconstruir a presença de proprietários de terras na regiáo, principalmente no que se refere às açôes relacionadas a outros engenhos, embora o foco da análise recaia no engenho Aproaga, muitas vezes noticiado pela imprensa como uma espécie de fortaleza que servia de moradia, prisão, local de tortura e hospedagem.

Palavras-chave: conflitos; política; engenho; Aproaga; rio Capim.

\section{A fortress sugar mill: land, politics and heritage on the Capim River, PA, during the second half of the 19th Century}

\section{ABSTRACT}

This study analyzes two members of the Chemont de Miranda family's interactions in political quarrels in order to reconstruct the relationships between political power, social prestige and patrimony among sugar and rice mill owners in the Capim River basin. To understand the mill owners' power, this article also reconstructs the presence of landowners in the region and their actions with one another. The article focuses on Aproaga mill, often reported by the press as a type of fortress that served as a place of dwelling and lodging as well as a prison and place of torture.

Keywords: conflicts; politics; sugar mill; Aproaga; Capim River.

DOI: http://dx.doi.org/10.1590/2237-101X02204815

Artigo recebido em 2 de maio de 2020 e aceito para publicaçáo em 17 de novembro de 2020.

* Professor da Universidade Federal do Pará / Centro de Filosofia e Ciências Humanas, Belém/PA - Brasil.

E-mail: wgaiafarias@gmail.com. ORCID: https://orcid.org/0000-0003-3088-0320. 


\section{Un ingenio fortaleza: tierra, política y herencia en el río Capim - PA, segunda mitad del siglo XIX}

\section{RESUMEN}

El estudio procura reconstruir las relaciones entre el poder político, prestigio social y patrimonio de los dueños de ingenios de azúcar y arroz, en la región del río Capim, partiendo de la actuación de dos integrantes de la familia Chermont de Miranda en las querellas políticas. Con el objetivo de comprender el ejercicio del poder de los propietarios de ingenios, la investigación también busca reconstruir la presencia de los propietarios de tierras en la región, principalmente en lo referente a las acciones relacionadas a otros ingenios, aunque el foco de análisis recaiga en el ingenio Aproaga, muchas veces noticiado por la prensa como una especie de fortaleza, que servía de vivienda, prisión, lugar de tortura y hospedaje.

Palabras Clave: conflictos; política; ingenio; Aproaga; río Capim.

\section{Introdução}

Este trabalho investiga a formação do poder de sujeitos que se envolveram em disputas políticas na região do rio Capim, na segunda metade do século XIX. A região em estudo situa-se no Estado do Pará, a 137 quilômetros de Belém, na foz da bacia do extenso rio Capim, sendo área de colonização desde o século XVII, embora com maior investimento da empresa colonial em meados do século XVIII.

Considerando que as fontes analisadas levaram a indícios de formação de famílias e grupos sociais no século anterior ao período recortado na pesquisa, em alguns momentos foi necessário dedicar a atenção ao século XVIII, no intuito de recuperar elementos importantes à compreensão do desenvolvimento desses poderes e das dinâmicas produtivas relacionadas à constituição do poder, considerando as relaçóes sociais desses agentes com trabalhadores escravos, libertos ou homens livres pobres nos engenhos e comunidades da região.

A compreensão sobre sociedades em pesquisas com perspectivas de análises de longa duração nos remete a Fernand Braudel (1984) em seu O Mediterrâneo, ao tratar das permanências em várias dimensóes socioculturais, já que, de modo geral, o ponto central da análise desse historiador, dentre outras questôes, repousa no entendimento da vasta região mediterrânea, enquanto zona de intercâmbio entre sociedades que viviam e/ou estabeleciam relaçóes comerciais. Nessa diretriz, a obra de Braudel é um convite ao entendimento de permanências como costumes, tradições, trocas culturais, encontros de grupos sociais e relações com o mundo natural, além de questóes no âmbito do poder.

Essas liçõos de Braudel ajudam a desvendar os valores construídos em um tempo longo, nesse caso, no rio Capim, guardadas as particularidades, em que o processo de colonização 
deixou heranças socioculturais, políticas e econômicas e outras questôes tratadas neste artigo. Contudo, nesta investigaçáo, o fio condutor das dimensóes abordadas são os Chermont de Miranda e as famílias formadoras no século XIX, e o olhar ao XVIII objetiva apenas demonstrar questóes relacionadas à produção nos engenhos da região e redes de relaçôes sociais e poder.

A princípio discutirei a exploração das terras do Capim, no século XVIII, quando famílias receberam sesmarias da Coroa portuguesa, investiram na produção agrícola, resultando na formação de importantes bases de comunidades. Depois analisarei a força dos senhores na sociedade imperial, partindo de consideraçôes historiográficas sobre clientelismo e os negócios envolvendo familiares e agregados no oitocentos, passando pelo processo de ampliação de fortunas de famílias proeminentes na ordem monárquica que se tornaram matrizes dos Chermont de Miranda, e que a estes deixaram bens materiais e imateriais. Tratarei do processo de fortalecimento do prestígio e poder dos Chermont de Miranda, identificando o trânsito e teias de relaçôes constituídas pelos irmãos Pedro e Vicente, a partir dos usos de códigos sociais, negociaçôes e atuaçóes, inclusive referentes a disputas políticas com o uso da violência física. Essa discussão é balizada pelo debate sobre as trajetórias das famílias Chermont de Miranda e formadoras, analisadas como unidades sociais-mercantis por valorizarem a produção da riqueza e a geraçáo de patrimônio na escalada da família nos espaços de ascensão e manutenção de poder das elites econômicas e políticas. Nessa diretriz, nos negócios de família estão os casamentos, compadrio, heranças e prestígio social.

\section{A regiáo do rio Capim e seus engenhos}

Em 1780 o mestre de campo André Miguel Aires informava aos oficiais do Senado da Câmara de Belém do Pará sobre a necessidade de aquisição de escravos negros para servir no seu engenho, situado nas margens do rio Capim, pois se tratava de engenho real' ${ }^{1}$.

De acordo com André Aires, em 1758 houve investimento na construçáo de engenhos de açúcar e alambique com estrutura "grandiosa", com a utilização de grande número de indígenas. E, em seguida, ocorreu a compra de escravos negros (não há especificação de quantidade de escravos) no valor total de dois contos e quinhentos e trinta mil reis. Estes passaram a trabalhar junto aos indígenas e soldados, atuando na Fazenda Real e de particulares, pois mesmo após a Lei de 6 de julho de 1755, os indígenas permaneceram sob a tutela do Estado, que, por meio da administração do Diretório pombalino, explorava a sua força de trabalho (PAZ, 2020). Os negros, tratados no documento genericamente como "etío-

\footnotetext{
${ }^{1}$ AHU_ACL_CU_013, Cx. 87, D. 7088. Officio de André Miguel Aires para os [oficiais do Senado da Câmara da cidade de Belém do Pará]. Pará, 28 nov. 1780. Projeto Resgate - Pará (1616-1833). A abreviação AHU refere-se ao Arquivo Histórico Ultramarino e as complementaçôes à identificação do Projeto Resgate, disponível no site http://resgate.bn.br/docreader/docmulti.aspx?bib=resgate.
} 
pes", foram preferidos sob o argumento de serem mais resistentes e aplicados à cultura das lavouras, possivelmente em relação aos indígenas e homens brancos pobres. Segundo André Aires, naquele ano havia vinte escravos capazes de trabalho no canavial e "sete escravos menos capacitados", quatro escravos aplicados ao trabalho da "lavoura de farinha necessária ao sustento de todos" e mais oito escravos que não podiam trabalhar no engenho por serem considerados "catrapiados", possivelmente por apresentarem limitaçôes por traumas físicos. Também contava com dois escravos ferreiros e dois carpinteiros que atuavam em atividades do engenho, nove indígenas homens e mulheres, capazes de trabalhar no canavial, sete "incapazes desta atividade", duas indígenas trabalhando na casa, dois no trabalho de engenho, dois pescadores e um caçador ${ }^{2}$.

Para moer no engenho era preciso trinta "servos", para o canavial seriam vinte, no engenho "dez pessoas para trabalhar de dia e dez a noite". Para a fornalha seriam necessárias quatro pessoas. Destas, duas trabalhavam durante o dia e duas à noite, porém havia o emprego de mais doze pessoas para atuar na casa de purgar e seis aos demais serviços.

A força de trabalho e quantidade de cana apresentada por André Aires era para a produção de 700 arrobas de açúcar, quantidade bastante expressiva. Além desse canavial, o mestre de campo ainda fazia referência à demanda de outro lavrador que tinha muita cana plantada e que também necessitava de mais mão de obra para garantir uma boa produçáo de açúcar. Na descrição das atividades desenvolvidas no processo produtivo do engenho, há preocupação com os períodos de trabalho durante as "invernadas", momento de baixos resultados e de muito trabalho. Mas é preciso considerar outros fatores, como o ambiental, os mecanismos e tecnologias dos engenhos, para compreender questôes fundamentais ao funcionamento destes e da exploração de mão de obra ${ }^{3}$. Em outro ofício, de 2 de julho de 1761, André Miguel Aires informava ao Secretário de Estado da Marinha e Ultramar, Francisco Xavier de Mendonça Furtado - irmão do Marquês de Pombal, que elevou São Domingos da Boa Vista a distrito, em 1758 (MIRANDA, 1982) - a situaçáo geral dos engenhos e plantaçóes de açúcar de sua propriedade e das dificuldades em obter escravos e, por isso, solicitava a introduçáo de maior número de escravos à Coroa portuguesa, justificando que tinha maior possibilidade de produção de açúcar na região e de negócio a fazer com a Companhia de Comérción .

Ofícios de André Aires recorrendo à Coroa para obtenção de mão de obra escrava não foram a única questão envolvendo os engenhos reais do rio Capim. No ano de 1788, Silvestre José Lopes e sua mulher, Luísa Caetana Martins, enviaram um requerimento à rainha Dona Maria I, solicitando "provisão de confirmação da sociedade que fizeram com Teodoro

\footnotetext{
${ }^{2}$ Idem.

${ }^{3}$ Idem.

${ }^{4}$ AHU_ACL_CU_013, Cx. 50, D. 4542. Offício de André Miguel Aires para o [secretário de estado da Marinha e Ultramar], Francisco Xavier de Mendonça Furtado. Pará, 2 jul. 1761. Projeto Resgate - Pará (16161833).
} 
de Oliveira e sua mulher Joaquina Teresa Martins", em um engenho de "moer canas e de descascar arroz", no rio Capims.

O trabalho numa fazenda de açúcar levava em consideração as atividades referentes ao canavial, de onde saía a principal matéria-prima e empregava maior número de trabalhadores que, na Amazônia, ocorria na maior parte do ano e, dependendo da produtividade variava o quantitativo de força de trabalho. A esse respeito André Miguel Aires informava que, para moer no engenho era preciso vinte "servos", sendo dez para o trabalho diurno e dez para o noturno ${ }^{6}$. Nessas unidades produtivas - "O uso das rodas d'água caracterizava os engenhos reais [...]" (FERLINI, 1988, p.116), o que era predominante na produção de açúcar e aguardente na Amazônia.

A região do rio Capim produzia açúcar e arroz nos chamados engenhos reais, alguns dos quais possivelmente fossem ainda produtivos no século XIX, mantendo o mesmo tipo de funcionamento dos descritos acima. Outra questão importante a considerar é que, pelas atividades de trabalho e preocupação em garantir a produtividade antes do período de chuvas intensas na Amazônia (de fevereiro a abril), alguns engenhos produziam em dois grandes turnos: diurno e noturno.

Os dois engenhos que, no século XIX, pertenciam à família Chermont de Miranda, o Taperuçu e o Aproaga, situavam-se em áreas de várzea baixa, contando com as águas do rio nas marés diárias para garantir funcionamento dos moinhos o ano inteiro, diferentes dos engenhos localizados em áreas de várzea alta ${ }^{7}$ que só contavam com marés diárias no período de fevereiro a abril, mas também quando precisavam adequar as atividades diárias devido à inundação na maior parte do dia (MARQUES, 2015). Isto implicava a necessidade de produção diurna e noturna, de acordo com o horário das marés ${ }^{8}$, o que demandava maior emprego de força de trabalho e a intensificaçáo da exploração de mão de obra.

No século XIX, São Domingo de Boa Vista era distrito de Belém e contava com a Freguesia de Sant'Anna. No total, na regiáo do Capim, em 1872, havia cerca de 63.465 habitantes, dos quais 640 eram eleitores e 7.277, escravos. Sant'Anna, era a área mais povoada, com 5.238 moradores $^{9}$, onde localizavam-se os engenhos Aproaga e Taperuçu, que produziam açúcar, aguardente e arroz, produtos também produzidos no engenho do Calisto. Este, cons-

\footnotetext{
${ }^{5}$ AHU_ACL_CU_013, Cx. 91, D. 7088. Requerimento de Silvestre José Lopes e de sua mulher Luísa Caetana Martins. Pará, 8 jul. 1788. Projeto Resgate - Pará (1616-1833).

${ }^{6}$ AHU_ACL_CU_013, Cx. 87, D. 7088. Officio de André Miguel Aires para os [oficiais do Senado da Câmara da cidade de Belém do Pará]. Pará, 28 nov. 1780. Projeto Resgate - Pará (1616-1833).

${ }^{7} \mathrm{Na}$ Amazônia há dois tipos de terras: as altas e as baixas e três subdivisóes do tipo terras baixas que são a área não inundável, classificada como várzea alta; a área periodicamente inundável, chamada de várzea baixa, e a área permanentemente inundada, classificada como igapó.

${ }^{8}$ As bacias dos rios próximos à foz do Amazonas sofrem os efeitos das marés, mesmo estando em alguns pontos a mais de $200 \mathrm{~km}$ de distância do mar, sendo este os casos do rio Capim e Guamá.

${ }_{9}^{9}$ ARQUIVO PÚBLICO DO ESTADO DO PARÁ - APEP. Falla com que o Exm. Snr. General Visconde de Maracajú, presidente da Província do Pará, pretendia abrir a sessão extraordinária da respectiva Assembléa no dia 7 de janeiro de 1884. Pará, 1884, p. 29.
} 
truído em 1844, já com funcionamento a vapor. No final do oitocentos, em menor escala eram produzidos farinha, milho, feijão, tabaco, madeiras, borracha, cravo, copaíba, breu, aves, porcos, peles e frutas como bacuri, ananás, laranjas e abacates, para consumo interno e comercialização externa.

\section{A força dos senhores: famílias, clientes e poder}

Gilberto Freyre, em Casa Grande e Senzala, apresentou a família no centro da discussão sobre a formação da sociedade brasileira, destacando a força do patriarcalismo no processo de colonização. No entanto, a partir da década de 1970, outra vertente de pesquisadores, que optaram por entender diferentes aspectos da sociedade a partir das famílias, enveredou por novos tipos de fontes, métodos e perspectivas de análises. Como exemplos dessa vertente, cabe mencionar os trabalhos de Eni de Mesquita Samara (1977) e Mariza Corrêa (1993), que identificaram diferentes perfis de famílias, até entáo não destacados pela historiografia, como as nucleadas, formadas a partir de instrumentos considerados legais ou de concubinatos, sendo algumas chefiadas por mulheres pobres, negras, dentre outras. Essas pesquisas alavancaram muitas possibilidades de abordagens sobre diversificados tipos de famílias e relaçôes sociais, refutando, em certa medida, a noção de hegemonia da família patriarcal no Brasil (MUAZE, 2013).

Mariana Muaze defende que os estudos de história da família possibilitam a compreensão sobre "[...] as redes mais complexas de sustentação afetiva, cultural e de poder, tecidas pelas famílias de um dado grupo social", o que pode levar ao entendimento, tanto a respeito das condutas e comportamentos internos, como dos aspectos externos aos núcleos familiares, principalmente quando se abrem novas perspectivas de usos de fontes que "permitam adentrar o universo cotidiano das relaçôes afetivas tecidas entre os membros da família" (MUAZE, 2013, p. 19). Portanto, os estudos sobre as famílias, enveredando por esse viés, significam novos caminhos ao entendimento das açóes e valores de grupos sociais dominantes, nesse caso, na sociedade imperial.

Os casamentos nas classes dominantes também eram tidos como meios de manter ou ampliar as fortunas, o poder político e o prestígio social. Assim, muitas vezes resultavam mais produtos de negociaçóes e arranjos do que de jogos de sedução, encantamentos ou amores intensos. Em determinadas situaçóes, até mesmo os matrimônios endógenos eram bem aceitos. Esse tipo de união conjugal, por vezes, era amparado em situaçôes de manutenção ou ampliação de vantagens materiais e imateriais.

A obra de Sheila Castro Faria é um bom exemplo de novas abordagens, pois procura compreender a família de área rural do Rio de Janeiro no século XVIII, a partir de bens materiais, vida cotidiana e extensão de relaçôes sociais com grupos de convívio de sujeitos livres, 
libertos, escravos, ricos e pobres. Na pesquisa, Sheila Faria optou por utilizar inventários, registros paroquiais de batizados, casamentos e óbitos, processos matrimoniais, mapeamentos agrários e demográficos, obtendo resultados significativos (FARIA, 1998).

Na Amazônia, os estudos nesse campo têm apresentado importantes contribuiçôes, possibilitando diversos caminhos à compreensão da multiplicidade de relaçóes sobre as famílias. Estes são os casos das pesquisas de Cristina Cancela (2011) e Daniel Barroso (2012), que analisam diversificados conjuntos de fontes de procedências paroquiais e cíveis, como livros de batismo, processos de casamentos, testamentos e inventários post mortem; e criminais, como ocorrências policiais e processos criminais, além de periódicos, relatórios de presidentes de províncias e de governadores.

Como defende José Murilo de Carvalho (2010), o acesso de membros de famílias de proprietários aos meios políticos ocorria pelo trânsito destas nos espaços de sociabilidade dos grupos dirigentes. O vínculo com a máquina estatal era um importante caminho aos que galgavam posições de destaque e outras benesses no Império. Afinal, o Estado político restrito (GRAMSCI, 1968) à época não era um circuito fechado, porém adentar nos espaços requeria o preenchimento de alguns requisitos. De toda sorte, os aspirantes à ascensão social e política nesses jogos do poder deveriam ter algumas habilidades. Com frequência, os ricos senhores, sobretudo em meios rurais, investiam em obras de usos públicos, como escolas, cemitérios, igrejas, hospitais, pontes, abertura de estradas e outras, que poderiam até ser da alçada do Estado, mas quando financiadas pela iniciativa privada se apresentavam como vias para compromissos de reciprocidade e fidelidade. Náo seria exagerado afirmar que os poderes foram se reformulando por mais de um século, mesmo sendo possível compreender que as dinâmicas políticas que constituem elites locais podem ser melhor explicadas pelo estreitamento dessas relações (CARVALHO, 2010).

$\mathrm{Na}$ base da família Miranda está o negociante português Vicente Antonio de Miranda, que faleceu em 1846, deixando seis filhos. O primeiro foi Vicente Antonio de Miranda Junior, que morreu seis anos após o pai, antes da partilha de bens, mas ainda deixou expressivo patrimônio aos irmáos ${ }^{10}$. Francisco Antonio faleceu em 1853, deixando herança à esposa e filhos ${ }^{11}$. Antonio José e José Antonio, além da herança do pai, dividiram também os bens deixados por Vicente Junior, não havendo nenhum quinhão em nome de outros irmãos. Mas, em 1864, Antonio José de Miranda já era falecido e seus bens, como o engenho Aproaga, muitos escravos e imóveis, ficaram para a esposa e filhos ${ }^{12}$. José Antonio de Miranda viveu até março de 1879. Solteiro, este deixou muitos escravos, o engenho Taperuçu, casas, terrenos e prédios alugados na capital paraense, e, apesar de ter uma filha, seus sobrinhos Vicente e Pedro, filhos do fale-

${ }^{10}$ CENTRO DE MEMÓRIA DA AMAZÔNIA - CMA. 2a Vara Cível/Ódon, Inventário de Vicente Antônio de Miranda, Belém, 1853.

${ }^{11}$ APEP. Catálogo Judiciário: Juízo de Órfãos da Capital, cx. 16, Inventário e Partilha de Bens, pasta 3, 1853.

${ }^{12}$ APEP. Catálogo Judiciário: Juízo de Órfãos da Capital, caixa 28, Inventário e Partilha de bens, pasta 02, 1864. 
cido Antonio José, também herdaram parte de seus bens ${ }^{13}$. Sobre os irmãos Pedro Antonio e João Antonio de Miranda não encontrei dados quanto ao patrimônio e herança, porém, como o irmão Vicente Junior, não tiveram filhos (MIRANDA, 1982, p. 42).

$\mathrm{Na}$ formação da família Chermont de Miranda encontrei o casamento do comendador Antonio José de Miranda com Inês de Lacerda Chermont, que tiveram dois filhos e uma filha: Vicente, Pedro e Florípes. Os dois filhos permaneceram por muito tempo no rio Capim, sendo os senhores de engenho mais destacados na imprensa da época (MIRANDA, 1982, p. 64).

Antonio José foi deputado provincial em duas legislaturas ${ }^{14}$ e bastante dedicado aos investimentos, como o vapor Guajará adquirido em 1858, encomendado a um estaleiro londrino para fazer viagens de passageiros e cargas nos trechos de Belém a Vigia de Nazaré, e de Belém a Cametá ${ }^{15}$. Contava com investimentos na produção de arroz no rio Capim e vendia nos armazéns em Belém. Extraía, comprava e vendia madeira em Belém, no estabelecimento onde adquiria "partidas de toros de cedro, e outras madeiras próprias de cerrar, e recebe-as na fábrica de serrar, cita a margem da Doca do Reducto"16. Conhecido como hábil investidor, Antonio José de Miranda utilizava a imprensa para fazer negócios, tais como anunciar aluguéis de imóveis, solicitar averbação de terras do poder público, divulgar os horários de viagens e as cargas consignadas no vapor Guajará, cobrar vencimentos de hipotecas, leiloar bens hipotecados, anunciar venda de produtos agrícolas, dentre outros investimentos.

José Antonio de Miranda também possuía um patrimônio expressivo, mas com vida social e política bem mais moderada. Além dos investimentos em parceria com Antonio José, produzia arroz e açúcar no engenho Taperuçu e, dos irmãos Miranda, foi o que viveu mais tempo, passando por uma fase de transtornos psicológicos apresentados pela imprensa como "demência"17. No entanto, bem antes de sua morte, em 1879, publicou no jornal O Liberal do Pará $^{18}$ uma nota informando que havia retirado a administração de seus bens das mãos do "Sr. Antonio Joaquim Soveral Barbuda e que constituiu seus bastantes procuradores srs. dr. Vicente Chermont de Miranda, dr. Felipe José de Lima e Antonio Ferreira Bentes".

No inventário de José Antonio de Miranda consta o engenho Taperuçu, muitos imóveis urbanos herdados de seu pai e outros adquiridos com recursos provenientes de seus investimentos, como 217 escravos. José Antonio morreu solteiro, mas tinha uma filha chamada Estephania. No entanto, no inventário consta como principal herdeiro o seu sobrinho Vicente Chermont de Miranda, que foi um de seus procuradores, e isto causou grande discussão na imprensa, pois os conservadores apresentavam a situação como um golpe dos irmãos Chermont de

\footnotetext{
${ }^{13}$ CMA. 2a Vara Cível/Ódon, Inventário do capitão José Antonio de Miranda. Belém, 1879.

${ }_{14}$ Treze de Maio. Belém, 8 abr. 1856, p. 2.

${ }^{15}$ Gazeta Official. Belém, 1 out. 1858, p. 4.

16 Treze de Maio. Belém, 22 nov. 1853, p. 4.

${ }^{17}$ A Constituição. Belém, 5 abr. 1879, p. 1.

${ }^{18}$ O Liberal do Pará. Belém, 4 ago. 1875, p. 2.
} 
Miranda. Durante alguns dias o patrimônio deixado por José Antonio ocupou as páginas dos jornais ligados aos Partidos Liberal e Conservador, como centro de debate político-partidário.

Theodósio Constantino Chermont era pai de Inês de Lacerda e de Antonio de Lacerda Chermont, Barão e depois Visconde do Arary. Sobre essa família há uma série de histórias com referências à situação econômica confortável de seus integrantes. Nesse sentido, chama atenção a matéria do jornal $O$ Democrata, de 1890 , sobre 1.000 barras de ouro que o engenheiro Theodósio Constantino, ainda no final do século XVIII, teria enterrado em sua chácara conhecida como Tapera Chermont, situada nas ruas, à época conhecidas como Caminho do Tucunduba e Estrada do Maranháo. Estas, na respectiva ordem, atualmente são a Avenida Conselheiro Furtado e a Rua Nove de Janeiro ${ }^{19}$.

Nos inventários dos membros da família Chermont de Miranda e das que formaram esse ramo, é evidente o acúmulo de muitos imóveis urbanos, sendo alguns alugados para instituições públicas e privadas. $\mathrm{O}$ aluguel de imóveis parecia ser um bom negócio que garantia vantagens à família e, somado aos recursos provenientes dos investimentos nos engenhos de açúcar, possibilitava boas reservas.

Há dificuldades para levantar os rendimentos das "famílias de posse" com imóveis alugados nas cidades, pois muitos desses inventários não apresentam valores e tipos de negociaçôes. A respeito dessas fortunas inventariadas, Cristina Cancela defende que havia homens ricos que diversificavam seus investimentos em atividades como a criação de gado, produção de açúcar e arroz, seringais, aluguel de imóveis urbanos, dentre outros investimentos (CANCELA, 2011, p. 310). Este é o caso dos inventários post mortem dos Chermont de Miranda e famílias matrizes formadoras destas.

Sobre a sociedade do século XIX, Graham afirma que as relações interfamiliares chegavam até a levar uma tensão entre pobres e ricos no que tratava de hierarquia social e obediência. Defende, ainda, que esses padróes sociais tinham peso significativo na vida política, que, "Embora na realidade famílias e unidades domésticas aparecessem de várias formas, o ideal partilhado universalmente tomava como certo que fossem chefiadas por um homem" (GRAHAM, 1997, p. 34). Legal e culturalmente, o pai tinha autoridade sobre os filhos e esposa, com direito de punir os membros da família. Essa autoridade, quando se tratava de poderosos proprietários de terras, também se estendia aos escravos, agregados, afilhados e outros que recorriam a sua proteção.

Graham (1997, p. 35) defende que para as famílias de posse as relações sociais representavam "importante fonte de capital político" que, geralmente, se voltavam à tarefa de garantir o aumento da propriedade por várias geraçôes, seja por meio de negociaçóes econômicas, conquistas e manutenção de cargos administrativos, mandatos políticos e bons casamentos, já que, uma vez envolvidas, as famílias votavam juntas. A atuação das famílias, muitas vezes se estendia para além dos pais, esposas e filhos, sobretudo, em se tratando de famílias de grandes

${ }^{19}$ O Democrata. Belém, 6 jul. 1890, p. 1. 
proprietários rurais revestidos de poderes e prestígio social que estabeleciam relacionamentos consanguíneos e de compadrio, já que geralmente eram procurados para apadrinharem filhos de pessoas de posiçóes subalternas na hierarquia social. Os laços construídos por meio dessas relaçôes geravam relaçôes mútuas, pois, o padrinho assumia compromisso de proteger seus afilhados e compadres, e estes cumpririam sua parte com a obediência. No caso de fazendas, até mesmo escravos libertos e outros tipos de agregados poderiam fazer parte da família.

Havia os casos de famílias poderosas assumirem papel de liderança de um grupo de várias famílias que lhes deviam favores, apoio político e obediência. Segundo Graham, os líderes garantiam apoio a todos. Não por acaso, muitas vezes essas lideranças formavam fortes grupos armados, chegando até mesmo a serem mais fortes numérica e belicosamente do que os efetivos policiais das pequenas cidades dessas áreas, e até mesmo "escravos fugitivos podiam receber essa proteção de um escravocrata” (GRAHAM, 1997, p. 39).

Estando no topo dessas relaçóes, o proprietário rural poderia exercer sua autoridade e ser influente com juízes, delegados e subdelegados. Essas relaçóes, por vezes, eram definidoras de posiçóes sociais e distinçôes entre as pessoas de família, com ou sem posses: ricos e pobres. Mas, de alguma forma; "Todos eram enredados num processo constante de troca mútua, embora desigual. Em suma, a elite mantinha a ordem social por meio de uma visão (geralmente compartilhada) de que a obediência fazia jus à proteção" (GRAHAM, 1997, p. 43).

Partindo das críticas de José Murilo de Carvalho a Graham, quanto à concepção que apresenta o clientelismo como força a-histórica que se impóe ao Estado e às formas de sociabilidades, Ivan Vellasco, além de ratificar essa posição, acrescenta que os novos estudos sobre famílias permitiram o alargamento da compreensão das relaçôes entre grupos sociais e o Estado imperial na formação das clientelas. Essas questóes são evidentes nas relaçôes intraelites. Mas as redes de clientelas não se encerravam "na relação de dominação e submissão" (VELLASCO, 2009, p. 89). Desse modo, as contribuiçôes dos estudos recentes sobre famílias e elites do século XIX são visualizadas no tratamento de temas que fogem à simples lógica dos jogos de interesses na dimensão da dominação unilateral dos grupo dominantes e, passam a enfatizar as situaçóes de reciprocidade e tradiçóes explicadas a partir de um conjunto maior de valores de mutualidade, sociabilidade, pertencimento, códigos simbólicos, condutas, formas de reprodução social, trocas de experiências e outras questôes da imbricada teia de relaçôes sociais. Não obstante, há importantes abordagens de Richard Graham que contribuem sobremaneira neste artigo.

\section{Os irmãos Chermont de Miranda: prestígio e poder}

Pedro e Vicente Chermont de Miranda, atuando em Sáo Domingo da Boa Vista, principalmente na Freguesia de Sant'Anna, se destacaram pelo ativismo político no final da Mo- 
narquia e início da República. Estes seguiram a tendência de negócios das famílias maternas e paternas e investiram na produção de arroz, açúcar e criação de gado, além de ocuparem cargos públicos e manterem muitos imóveis alugados na capital paraense. Esses irmãos, juntos com Florípes, contaram com boas heranças dos Chermont, ramificação materna e, talvez, maior ainda dos Miranda, advinda do lado paterno, e tiveram atuação destacada durante as décadas de 1870, 1880 e início de 1890 à frente dos engenhos Taperuçu e Aproaga, e outros negócios em Belém e nas fazendas em Camará, Monsarás, distrito de Salvaterra, cidades de Soure e Cachoeira do Arary, no arquipélago marajoara ${ }^{20}$ (BATISTA, 2014, p. 197).

Pedro foi subdelegado de Sant'Anna do Capim na década de 1870 e vereador em Belém no período de 1876 a 1879, estando envolvido em uma série de conflitos em açôes contra os conservadores, pelo menos até a metade dos anos de 1880, quando passou a dedicar-se mais aos negócios na capital paraense e às viagens a Paris, onde adquiriu imóvel (MIRANDA, 1982, p. 65).

Vicente estudou em Portugal, mas foi na Universidade de Gant (Bélgica) que, na primeira metade da década de 1870, se formou em engenharia industrial. Casou-se com a holandesa Carolina Maria Magdalena Van Gysellar. E, como o irmão, também foi vereador, de 1880 a 1883, e chegou a assumir o cargo de intendente de Belém em 1882, na ocasião da morte de José da Gama Malcher (MIRANDA, 1982, p. 46).

Juntamente com o irmáo, Vicente Chermont de Miranda teve uma trajetória com participação ativa em conflitos no Capim, a ponto de ser chamado de "Heróe do Aproaga" pela imprensa oposicionista da época ${ }^{21}$. As suas açóes na região são destacadas, pelo menos no período que vai de 1875 a 1893, seja sob a Monarquia, como membro do Partido Liberal, ou no alvorecer republicano como principal liderança do Partido Republicano Democrático. Falava-se do engenho Aproaga, o mais destacado de todos, como uma verdadeira fortaleza e moradia dos Chermont de Miranda, com grande quantidade de armas e munições e como local onde escondiam-se os aliados foragidos da polícia, prendiam e torturavam os opositores políticos.

Até o final do século XIX, os irmáos Chermont de Miranda tiveram forte presença no rio Capim, onde envolveram-se em uma série de querelas políticas. Entretanto, Vicente também tem seu nome ligado às ciências, principalmente no período em que já não estava tão imerso nas querelas políticas do Capim, passando a viver na Ilha de Marajó, onde dedicou-se à criação de gado e voltou-se aos escritos sobre fauna, flora, vocábulos e culturas. Vicente também recebeu e hospedou viajantes intelectuais e expedicionários nos engenhos de Aproaga e nas fazendas do Marajó 22 $^{2}$, pois tinha trânsito no meio intelectual, sendo um

${ }^{20}$ APEP. Catálogo Judiciário: Juízo de Órfãos da Capital, caixa 28, Inventário e Partilha de bens, pasta 02, 1864.

${ }^{21}$ A Constituição. Belém, 2 mar. 1879, p. 1.

${ }^{22}$ MUSEU PARAENSE EMÍLIO GOELDI. Relatório apresentado ao Exmo. Sr. Secretário da Justiça, Interior e Instrucção Pública pelo Director do Museu Paraense. Boletim do Museu Paraense Emílio Goeldi 
grande incentivador das ciências pelo Museu Paraense de História Natural e Ethnographia, para onde doou catálogos e coleçóes de espécies vegetais e animais, como um jacaré-açu ${ }^{23}$. E, sob a administração de Antonio José de Lemos, foi um grande colaborador do Horto Municipal de Belém ${ }^{24}$.

Vicente publicou as obras Marajó: estudos sobre seu solo, seus animaes e suas plantas (1894) e o conhecido Glossário paraense ou colleção de vocábulos peculiares à Amazônia e especialmente a ilha de Marajó (MIRANDA, 1968), e também é lembrado por ter sido o introdutor de búfalos da raça Carabao, importados da Itália, na regiāo Amazônica, e como ex-presidente da Sociedade Paraense de Agricultura (PICCININ, 2007, p. 2).

$\mathrm{Na}$ área do rio Capim, Vicente e Pedro tinham amplos poderes. Essa força resultou de um longo processo, que contou com fortunas formadas pelo trabalho e por herança em bens móveis e imóveis, casamentos, dominação de meios de produção como engenhos, plantações e escravos, concentração fundiária e prestígio social que seus antepassados maternos e paternos construíram com trabalho, investimentos e, por cerca de um século, de relaçóes com as coroas portuguesa e brasileira, levando-os à obtenção de títulos de nobreza, cargos, comendas e sesmarias. No Capim, Marajó e em Belém, havia múltiplas relaçóes sociais de longas datas, estabelecidas por seus tios, pais, avós e pelas relaçóes de amizades, alianças, compadrio (BARROSO, 2012).

Os integrantes das famílias Chermont e Miranda ocuparam cargos públicos de direção e tiveram mandatos na Assembleia Provincial, talvez na maioria dos casos com a preocupação de garantir influência e posição privilegiada para fazer bons negócios. Contudo, entre os descendentes dessas famílias, Vicente Chermont de Miranda teve envolvimento bem mais intenso na vida política paraense no tempo da Monarquia, pelo Partido Liberal. Já no período republicano se opôs ao primo, Justo Chermont, do Partido Republicano Paraense - PRP, que governou o estado da Proclamação a 1891, quando foi nomeado para condução do Ministério das Relaçôes Interiores e Exteriores. Durante os mandatos dos governadores Duarte Huet Bacellar P. Guedes e Lauro Sodré, Vicente investiu em pelo menos três açôes lideradas pelo Partido Republicano Democrático - PRD, que estava sob sua presidência.

O prestígio de Vicente era táo grande que, mesmo durante a Revolta de 11 de Junho de 1891, no momento de proposição de negociaçôes com os revoltosos acampados na chácara Cacaolinho, na capital paraense, foi chamado pelo governador do estado para que resolvesse a situação, pois mesmo negando envolvimento, era o presidente do PRD. Portanto, a revolta

de História Natural e Ethnographia, do ano de 1902, p. 485. http://repositorio.museu-goeldi.br:8080/jspui/ handle/mgoeldi/1166.

${ }^{23}$ MUSEU PARAENSE EMÍLIO GOELDI. Relatório apresentado ao Exmo. Sr. Dr. José Paes de Carvalho, Governador do Estado do Para pelo Director do Museu Paraense. Boletim do Museu Paraense Emílio Goeldi de História Natural e Ethnographia, do ano de 1897, p. 11. http://repositorio.museu-goeldi.br:8080/jspui/ handle/mgoeldi/1151.

${ }^{24}$ O Pará. Belém, 30 abr. 1898, p. 2. 
terminou com uma negociação, por seu intermédio ou ordem. Após o fim da contenda, Vicente Chemont foi deportado para Lisboa (cidade portuguesa onde já havia estudado), mas em pouco tempo regressou ao Pará legalmente, amparado pelo decreto de anistia de 5 de setembro de 1891, do governo da República do Brasil. De modo geral, as puniçóes foram mais brandas aos que tinham prestígio social, recursos financeiros e parentesco com políticos da base do governo paraense, como era o caso do líder democrata ${ }^{25}$.

Prestígio social, condições econômicas e poder político estão entrelaçados na trajetória de vida de Vicente e Pedro. Socializados a partir dos valores de famílias abastadas, os filhos de proprietários de engenhos e de grandes extensóes de terras, logo aprenderam os valores desse meio, sobretudo, em se tratando dos herdeiros do sexo masculino. Mas, além de suas investidas individuais, a constituição de tal prestígio foi alicerçada em um longo tempo e tem a ver com dominação fundiária e social. A dominação social no Capim foi constituída verticalmente, pois esses irmãos detinham os meios de produção, eram empregadores e exploradores de trabalho escravo e de libertos também, proprietários de engenhos, terras e equipamentos. Constituíram e mantiveram fortíssimos vínculos e verdadeiras teias de relaçóes sociais, pois contavam com o peso da influência social constituída por seus pais, tios e avós no interior e na capital, onde eram proprietários de muitos imóveis, administravam grandes rendimentos e tinham boas relaçóes com instituiçóes destacadas na sociedade paraense, fazendo parte das elites sociais, políticas e econômicas.

Parte da fortuna dessas famílias resultava de investimentos e aquisição de terras no meio rural, mas tinham presença marcante em Belém, espaço importante para administração de atividades, articulaçôes políticas, constituição e/ou manutenção de redes de sociabilidade e moradia, pois era relevante garantir presença nos espaços e meios sociais frequentados pelas elites políticas na capital.

A respeito da relação entre campo e cidade na Grã-Bretanha, Raymond Williams afirma que, com frequência, há associaçôes do campo como lugar de atraso, de vida simples e bucólica, onde reina a paz e a inocência. Essas percepçôes sobre o campo são acompanhadas das visóes sobre as cidades como espaços de vida moderna, comércio, conhecimentos e comunicaçóes. O autor lembra também das imagens negativas sobre os espaços urbanos marcados pelo barulho, ambiçôes, "mundialidades", administração etc. A respeito do campo, Williams também destaca que, ao considerar as realidades históricas, trata-se de um lugar de práticas diversificadas que envolvem atuação de "caçadores, pastores e empresários agroindustriais" (WILLIAMS, 2011, p. 11). Somam-se a estes, os arrendatários, latifundiários e as fazendas estatais. Mesmo se tratando da Grã-Bretanha, as contribuiçóes de Williams ajudam a pensar as relaçóes estabelecidas no ambiente rural da parte da Amazônia da qual esta pesquisa se ocupa e das inter-relaçóes entre campo e cidade. Do ponto

\footnotetext{
${ }^{25}$ UM DEMOCRATA. Os sucessos de junho ou o último motim político do Pará. Belém: Imp. Tavares Cardoso e Cia., 1891. p. 215.
} 
de vista do trabalho nos engenhos, com suas engrenagens importadas do Velho Mundo, há possibilidades de entender as dinâmicas nas relaçôes sociais de dominação. As contribuiçôes de Raymond Williams são relevantes, principalmente, por tratarem de dimensôes dos usos dos espaços em questão, mesmo que o rio Capim não tenha sido alcançado pelos Cercamentos, processo que para o autor de $O$ campo e a cidade: na história e na literatura foi peculiar na Inglaterra.

No Brasil do final do século XIX, as cidades eram espaços adequados aos contatos diversos e palco de diálogos que envolviam organizaçóes como as lojas maçônicas e sociedades secretas, em muitos dos pontos de encontro de letrados, agentes do poder, mas também lugar de manifestos em praças públicas com distribuiçôes de panfletos e outros escritos como os periódicos em crescente distribuição e tiragem por suas forças, enquanto veículos de comunicação e meios de debates, críticas literárias e políticas, propagandas e divulgação de estilos de vida (DUARTE, 2009; MELLO, 2007).

No Pará, a capital era lugar privilegiado de trânsito nos meios políticos, sociais e nos círculos de letrados. Costumes, modos de vida, valores, formas de vestir e de se apresentar em público foram assimiladas dos países europeus. As elites paraenses acreditavam estar de acordo com padrôes modernos de condutas, por isso ostentaram valores, passando a importar vestidos, chapéus, tecidos, gêneros alimentícios, dentre outros produtos, na tentativa de igualar seus costumes aos dos europeus, e, até mesmo, companhias de espetáculos do Velho Mundo eram contratadas para apresentaçôes em Belém (LACERDA, 2016).

As elites amazônicas acreditavam estar vivendo um momento próspero e pujante, denominado de Belle Époque, ocorrido entre os anos de 1870 e 1912 (SARGES, 2010). Naquela ocasião os poderes públicos do Pará e Amazonas buscaram investir na urbanização e modernização de suas capitais. Belém e Manaus foram as cidades mais expressivas, como centros urbanos e polos de investimento e negociaçáo de capital, e passaram a ser lugares de transformaçóes e conflitos relacionados a disputas pelo espaço entre as classes sociais antagônicas.

Os irmáos Chermont de Miranda cultivavam o respeito das comunidades nos meios rurais, o que de certa forma era transmitido de pai para filho e por meios já explicitados anteriormente. Por outro lado, despontavam de prestígios político e social estando no círculo do poder que lhes interessavam. Em Belém eram definidas questóes cruciais de dimensão política, mas também era o espaço onde ocorriam contratações para execução de obras públicas e outras oportunidades como aluguel de imóveis para as instituiçóes públicas. Portanto, o campo era lugar de produção agrícola, fabrico de açúcar e beneficiamento de arroz. Já a cidade, espaço de comercialização diversificada, de negócios com a administração pública e de desfrutar dos privilégios adquiridos por todas as dimensôes. 


\section{Aproaga: moradia, engenho e fortaleza}

O terreno do engenho Aproaga foi comprado por Vicente Antonio de Miranda no ano de 1839. Contudo, este faleceu poucos anos depois e a propriedade passou ao seu filho, Antonio José de Miranda, que mandou construir o engenho para produção de açúcar e fabricação de aguardente ${ }^{26}$. Com o falecimento do comendador Antonio José, o engenho foi herdado pelos irmáos Chermont de Miranda, que passaram a se destacar pelo envolvimento em conflitos que partiam do Aproaga.

No jornal O Liberal do Pará ${ }^{27}$, Vicente Chermont de Miranda publicou esclarecimento sobre as acusaçóes publicadas no diário A Constituição, de que teria usado seus escravos para resgatar à força um prisioneiro em poder do subdelegado Manuel Ignácio Pereira. Vicente afirmava que tudo seria resultado de calúnias do proprietário do engenho Santo Antonio, José Calisto Furtado, membro do Partido Conservador. Segundo O Liberal do Pará, jornal do Partido Liberal ao qual Vicente era filiado, tratava-se do carpina Paulo, um de seus trabalhadores, que teria sido preso injustamente pelo subdelegado Manuel Pereira, a pedido de José Calisto. No entanto, quando a escolta chegou à ponte, o prisioneiro fugiu em uma canoa, adentrando no engenho Aproaga, passando a ficar sob a proteção dos irmãos Vicente e Pedro.

O Liberal do Pará, de 25 de agosto de $1875^{28}$ tratou da chegada de uma lancha a Belém, que conduziu 12 soldados de linha, às ordens do delegado de polícia, que foi ao Capim e prendeu 11 escravos de Vicente Chermont de Miranda, cativos no engenho Aproaga. Segundo os liberais, as prisóes resultaram das tramas entre o proprietário de engenho Santo Antonio, José Calisto Furtado e de lideranças do Partido Conservador. O texto ainda remete a outros conflitos envolvendo liberais e conservadoras, em São Domingos da Boa Vista, inclusive com assassinatos e uso de escravos nos conflitos.

As trocas de acusaçóes e os conflitos envolvendo liberais e conservadores na regiáo em questão foram frequentes desde 1875, possivelmente ano de retorno de Vicente Chermont de Miranda, após seus estudos na Bélgica. Em julho de 1878, o jornal A Constituição publicou alguns depoimentos do chefe de polícia Miguel Lúcio de Mello Albuquerque sobre os conflitos na freguesia de Sant’Anna do Capim. Segundo o depoente Fortunato José Lopes, tudo teria começado na localidade conhecida como igarapé Jaboty-maior (algumas vezes chamada de rio), onde circulavam informaçóes de que os liberais acabariam com as igrejas. $\mathrm{Na}$ ocasião o padre Joaquim Gomes da Rocha procurou José Calisto no engenho Santo Antonio para que, juntos, resistissem às investidas dos liberais. De acordo com o depoente,

\footnotetext{
${ }^{26}$ INSTITUTO HISTÓRICO E GEOGRÁFICO BRASILEIRO - IHGB. Notação DL1228.031. Victorino Chermont de Miranda. Memorial das terras de propriedade de Pedro Chermont de Miranda às margens do rio Capim, no Pará. Engenho Aproaga e áreas circunvizinhas, 1855, 1856, 1876, 1904.

${ }^{27}$ O Liberal do Pará. Belém, 19 mar. 1875, p. 2.

${ }^{28}$ O Liberal do Pará. Belém, 25 ago. 1875, p. 2.
} 
o coronel Calisto, o padre e Manço Manito estariam arregimentando gente nos igarapés Caratateua e Jaboty-maior para tirar “as chaves da igreja das mãos do subdelegado de polícia do distrito de Sant'Anna do Capim, Pedro Chermont de Miranda, por bem ou por mal com mais de trinta pessoas" 29 .

Um oficial de justiça foi enviado pelo juiz, em diligência acompanhado do vigário, para intimar os irmáos Chermont de Miranda a entregarem as chaves, mas, ao chegar em Sant'Anna, na manhã de 20 de julho, encontrou a igreja matriz descoberta, "estando em seu redor um montão de pedaços de telhas, e o madeiramento, aliás de acapu e em bom estado de conservação, despedaçado e amontoado, sem arrumação, indicando visivelmente que o teto fora destruído com precipitação e não arrêado com vagar”. Vicente Chermont de Miranda teria ido "com muitos escravos seos na mesma madrugada..." para destruir a igreja matriz ${ }^{30}$. Essa questão foi tema muito explorado na imprensa paraense.

A situação de conflito em função das chaves da igreja resultou na prisão do "respeitável ancião coronel Calisto Furtado, e 19 inofensivos lavradores dedicados ao mesmo sr. coronel Calisto". Todos foram conduzidos a Belém pelo subdelegado de Sant'Anna do Capim, Pedro Chermont de Miranda. Na audiência, os irmãos Chermont de Miranda justificaram a prisão de Calisto e seus homens por receberem informações de que estes estavam preparando um ataque ao subdelegado para lhe retirarem as chaves da igreja. Após a audiência em Belém, os homens foram colocados em liberdade por meio de um habeas corpus, e Pedro Chermont de Miranda foi multado. Dez escravos do engenho Aproaga foram condenados, em sentença de julho de 1878, por tirarem um recruta das mãos da "autoridade policial". Mas o delegado de polícia, em execução da prisão definida pela sentença, prendeu apenas dois escravos, já que oito estavam no engenho sob a proteção dos proprietários ${ }^{31}$.

No dia três de agosto de 1878, no momento da eleição, uma lancha a serviço de José Calisto Furtado foi ao igarapé Pyrajauara para apanhar eleitores e conduzi-los às urnas. Porém, essa embarcação foi abordada por Vicente e Pedro que, à frente de cerca de cinquenta pessoas, entre soldados, homens livres e escravos, todos a bordo do barco de nome Aproaga, atiraram na lancha comandada pelo conservador Manito, que tinha a bordo mais cinco tripulantes e oito eleitores. Alguns foram atingidos pelos tiros e outros, espancados. Manito foi enviado ao hospital da Santa Casa de Misericórdia, bastante ferido ${ }^{32}$. Essas açóes me permitem lembrar da relação entre engenhos e política no Nordeste brasileiro, principalmente quando Vera Ferlini (1988, p. 102) defende que "Em torno dos engenhos proliferaram partidos de cana, fixando lavradores e sua escravaria [...]”, pois geralmente atraía pessoas para essas áreas devido ao impulso a outras atividades paralelas à produção principal. É bem provável que na região do rio Capim processo parecido tenha ocorrido e permanecido por longo tempo.

\footnotetext{
${ }^{29}$ A Constituição. Belém, 23 jul. 1878, p. 3.

${ }^{30}$ A Constituição. Belém, 25 jul. 1878, p. 3.

${ }^{31}$ A Constituição. Belém, 5 abr. 1879, p. 3.

${ }^{32}$ A Constituição. Belém, 6 ago. 1878, p. 3.
} 
Os irmãos Chermont de Miranda, a partir do engenho do Aproaga, administravam a produção e exerciam controle sobre muitas comunidades das margens do Capim. Para garantir esse controle empregavam recursos em armas, muniçóes, escravos e outros subordinados. O engenho causava medo aos inimigos dos irmãos, pois, a considerar as matérias publicadas nos jornais, serviu para prender e torturar inimigos e abrigar companheiros foragidos. Os moradores do Aproaga tinham grande conhecimento do que ocorria na área do Capim, por isso organizavam defesa e preparavam emboscadas com muita agilidade. Na segunda metade da década de 1870, ainda tinham a facilidade de contar com o cargo de subdelegado ocupado por Pedro Chermont de Miranda.

A nomeação aos cargos da estrutura policial no Império era prerrogativa dos presidentes de províncias na seguinte ordem: chefe de polícia da província, delegado do município e subdelegado de paróquias (estes com substitutos). E, como anota Graham no meio rural, “... a maioria possuía terras e buscava esses cargos públicos para exercer autoridade extra e estender favores, isenção e proteção aos seus apadrinhados" (GRAHAM, 1997, p. 87). O poder local dos delegados e subdelegados residia em suas prerrogativas legais de exercer o recrutamento forçado (para o Exército, Armada ou Guarda Nacional e outras corporaçóes policiais), o que era um importante instrumento de controle social em vigor em boa parte do século XIX, com forte influência dos homens de posses, juízes de paz e padres. Alguns patrôes, por suas influências, eram procurados por seus protegidos quando tentavam se livrar do recrutamento forçado (GRAHAM, 1997, p. 90).

Com o estabelecimento do regime republicano no Pará, a maioria dos integrantes do Partido Liberal se manteve no mesmo lado, mas sob a legenda do Partido Republicano Democrático - PRD, que passou a disputar o poder na República quando, até o ano de 1896, teve como seu principal adversário o PRP. Durante os primeiros anos do novo regime, Vicente Chermont de Miranda foi a maior liderança do PRD.

Durante o segundo semestre de 1890 a imprensa tratou de uma série de questóes sobre as disputas políticas entre republicanos e democratas em várias partes do estado do Pará. Em Belém, Pedro Paulo Baptista, chamado de Malaquias, Francisco Xavier da Veiga Cabral (Cabralzinho), Manoel João Coutinho e o sócio de Cabralzinho Francisco Martins, todos lutadores de capoeira, se evolveram em açôes contra os republicanos em diferentes localidades da capital e do interior do estado, com destaque para o distrito de Sáo Domingos da Boa Vista.

Vários artigos foram publicados nos jornais dos dois principais partidos políticos republicanos, tratando das buscas policiais, com o objetivo de promover a prisáo de ativistas democratas. Do PRD, na região do Capim, os mais atuantes foram Severino Lopes, Silvestre Lopes, João Francisco da Luz e Raymundo Ayres Franco. Os dois últimos eram homens de confiança de Vicente, estando sempre a seu lado nas situaçóes de conflitos, desde a Monarquia quando eram do Partido Liberal. Na década de 1880, como coronel comandante superior da capital 
da Guarda Nacional ${ }^{33}$, Vicente, os nomeou, respectivamente, capitáo e major, comandante da $3^{a}$ seçáo de infantaria da referida corporação. Na mesma ocasiáo também nomeou seu primo Teodósio de Lacerda Chermont ${ }^{34}$ e, talvez muitos outros amigos, parentes e aliados.

A tensão se intensificava à medida que se aproximava da abertura do Congresso Estadual Constituinte e a eleição do primeiro governador constitucional do Pará republicano, marcado para início de junho de 1891. No Capim, aconteceram muitos conflitos, levando o governo a enviar um destacamento à regiáo. No confronto, os policiais foram derrotados pelos democratas, liderados por Joáo Francisco da Luz, batendo em retirada com muitos feridos, e deixando no rio Capim dezenove mortos. Após alguns dias, os democratas seguiram do rio Capim para Belém, na tentativa de conquistar o poder por meio da Revolta de 11 de Junho de 1891, já contando com o apoio da maioria das praças do Corpo de Polícia. Mas, dessa vez, o evento terminou com a rendição negociada por Vicente Chermont de Miranda e a punição dos envolvidos (FARIAS, 2016, p. 263).

\section{Considerações finais}

Neste trabalho tentei demonstrar duas questóes relevantes. Primeiro, apresentando como o poder das principais lideranças do rio Capim foi edificado em um tempo longo e relacionado a questóes de terra, famílias, herança e política. Em seguida, tratei de aspectos do processo de disputas entre proprietários de engenho na regiáo estudada e, para isso, apresentei os contextos nos quais os proprietários de engenhos e seus subordinados envolveram-se em disputas políticas marcantes.

Acredito que náo se pode pensar nesses engenhos apenas como produtores de açúcar. A extração e comercialização de madeira das margens do Capim também já eram atividades desenvolvidas pelos proprietários de engenhos desde meados do século XVIII, pois as fornalhas consumiam muita lenha (FERLINI, 1988, p. 122). É possível que, até mesmo a diversificação da produção tenha sido uma estratégia para garantir o funcionamento dos engenhos de várzea baixa, sobretudo quanto à produção de arroz, já que contava com água diária para a irrigação.

Procurei demonstrar que o poder econômico, social e político dos irmãos Vicente e Pedro Chermont de Miranda foi constituído em um longo período, sendo fortíssimo na regiáo do rio Capim, no Marajó e mais tarde na própria capital paraense. $\mathrm{O}$ prestígio político deles pode ser explicado pelas trajetórias das famílias formadoras dos Chermont de

\footnotetext{
${ }^{33}$ APEP. Falla com que o Exm. Snr. General, Barão de Maracajú, presidente da Provincia do Pará, abrio a $2^{a}$ sessão da 23a Legislatura da Assembléa Legislativa da Província do Pará em 15 de fevereiro de 1883. Pará, 1883, p. 85 .

${ }^{34}$ APEP. Falla com que o Exm. Snr. General Visconde de Maracajú, presidente da Província do Pará, pretendia abrir a sessão extraordinária da respectiva Assembléa no dia 7 de janeiro de 1884. Pará, 1884, p. 43.
} 
Miranda, além das açôes individuais de Pedro e, principalmente, de Vicente, que, como já mencionado, frequentemente era chamado pelos oposicionistas de "Heróe do Aproaga". Daí o destaque a esse engenho como espaço múltiplo, legal e marginal, aparecendo como unidade produtiva, moradia dos proprietários, trabalhadores livres e escravos, fortaleza, onde os poderosos senhores do rio Capim prendiam e castigavam inimigos políticos e hospedavam e escondiam amigos e aliados. As ruínas e memórias desse engenho atualmente ainda são importantes marcadores de tempos e lembranças para as comunidades das margens do rio Capim, são memórias, casos contados e histórias de poder, escravidão, revoltas, mortes e produçáo (FARIAS, 2008).

A opulência, o prestígio da aristocracia senhorial e o cabedal cultural, sustentados pelas elites imperiais, eram quesitos que pesavam bastante na vasta rede de amizades. Contatos com famílias, investidores e grupos políticos influentes eram ditames seguidos pelos Chermont de Miranda e matrizes familiares formadoras. Mas, as influências de novos valores que chegaram ao Brasil, principalmente nas últimas décadas do oitocentos, aos poucos foram minando os modos de vida e valores hegemônicos de grupos sociais da ordem imperial. A reconfiguração dessas elites e a ascensão de outras, defensoras de alternativas mais liberais, individualistas e de caminhos mais verticalizadas de dominação social, política e, com bem mais apego aos aspectos econômicos nessa empreitada, estavam na base de um processo que iniciava com outros rearranjos do poder. Mesmo convivendo com algumas condutas e valores de aristocracia e nobiliarquia, as culturas políticas e de acumulação econômica, a ambiência cultural com paradigmas metropolitanos e internacionalizados com muita força alçavam voo e superavam valores vinculados ao país escravocrata com suas elites.

\section{Fontes documentais}

A Constituição. Belém, 5 abr. 1879.

A Constituição. Belém, 2 mar. 1879.

A Constituição. Belém, 6 ago. 1878.

A Constituição. Belém, 25 jul. 1878.

A Constituição. Belém, 23 jul. 1878.

ARQUIVO PÚBLICO DO ESTADO DO PARÁ - APEP. Catálogo Judiciário: Juízo de Órfāos da Capital, cx. 16, Inventário e Partilha de Bens, pasta 3, 1853.

APEP. Falla com que o Exm. Snr. General, Barão de Maracajú, presidente da Provincia do Pará, abrio a $2^{a}$ sessão da 23a Legislatura da Assembléa Legislativa da Província do Pará em 15 de fevereiro de 1883. Pará, 1883.

APEP. Falla com que o Exm. Snr. General Visconde de Maracajú, presidente da Provincia do 
Pará, pretendia abrir a sessão extraordinária da respectiva Assembléa no dia 7 de janeiro de 1884. Pará, 1884.

APEP. Catálogo Judiciário: Juízo de Órfãos da Capital, caixa 28, Inventário e Partilha de bens, pasta 02, 1864.

APEP. Falla com que o Exm. Snr. Conselheiro João Silveira de Sousa, abriu a $1^{\text {a }}$ sessão da $25^{\text {a }}$ legislatura da Assembléa Legislativa Provincial em 15 de outubro de 1884. Pará, 1884.

ARQUIVO HISTÓRICO ULTRAMARINO - AHU_ACL_CU_013, Cx. 87, D. 7088. Officio de André Miguel Aires para os [oficiais do Senado da Câmara da cidade de Belém do Pará]. Pará, 28 nov. 1780. Projeto Resgate - Pará (1616-1833).

AHU_ACL_CU_013, Cx. 50, D. 4542. Offício de André Miguel Aires para o [secretário de estado da Marinha e Ultramar], Francisco Xavier de Mendonça Furtado. Pará, 2 jul. 1761. Projeto Resgate - Pará (1616-1833).

AHU_ACL_CU_013, Cx. 91, D. 7088. Requerimento de Silvestre José Lopes e de sua mulher Luísa Caetana Martins. Pará, 8 jul. 1788. Projeto Resgate - Pará (1616-1833).

CENTRO DE MEMÓRIA DA AMAZÔNIA - CMA. 2a Vara Cível/Ódon, Inventário de Vicente Antônio de Miranda, Belém, 1853.

CMA. 2a Vara Cível/Ódon, Inventário do capitão José Antonio de Miranda. Belém, 1879.

Gazeta Official. Belém, 1 out. 1858.

INSTITUTO HISTÓRICO E GEOGRÁFICO BRASILEIRO - IHGB. Notação DL1228.031. Victorino Chermont de Miranda. Memorial das terras de propriedade de Pedro Chermont de Miranda às margens do rio Capim, no Pará. Engenho Aproaga e áreas circunvizinhas, 1855, 1856, 1876, 1904.

MUSEU PARAENSE EMÍLIO GOELDI. Relatório apresentado ao Exmo. Sr. Dr. José Paes de Carvalho, Governador do Estado do Para pelo Director do Museu Paraense. Boletim do Museu Paraense Emílio Goeldi de História Natural e Ethnographia do ano de 1897. Disponível em: http://repositorio.museu-goeldi.br:8080/jspui/handle/mgoeldi/1151. Acesso em: 5 mar. 2020.

MUSEU PARAENSE EMÍLIO GOELDI. Relatório apresentado ao Exmº. Sr. Secretário da Justiça, Interior e Instrucção Pública pelo Director do Museu Paraense. Boletim do Museu Paraense Emílio Goeldi de História Natural e Ethnographia, do ano de 1902. Disponível em: http://repositorio.museu-goeldi.br:8080/jspui/handle/mgoeldi/1166. Acesso em: 5 mar. 2020.

O Democrata. Belém, 6 jul. 1890.

O Liberal do Pará. Belém, 25 ago. 1875.

O Liberal do Pará. Belém, 4 ago. 1875.

O Liberal do Pará. Belém, 19 mar. 1875.

O Pará. Belém, 30 abr. 1898. 
Treze de Maio. Belém, 8 abr. 1856.

Treze de Maio. Belém, 22 nov. 1853.

UM DEMOCRATA. Os sucessos de junho ou o último motim político do Pará. Belém: Imp. Tavares Cardoso e Cia., 1891.

\section{Referências}

BARROSO, Daniel Souza. Casamento e compadrio em Belém nos meados do Oitocentos. Dissertação (Mestrado em História Social). Belém: Programa de Pós-Graduação em História Social da Amazônia. Universidade Federal do Pará, 2012.

BATISTA, Luciana Marinho. Muito além dos seringais: elites, fortunas e hierarquias no GrãoPará, c. 1850 - c. 1870. Belém: Editora Açaí, 2014.

BRAUDEL, Fernand. O Mediterrâneo e o mundo mediterrânico na época de Felipe II. São. Paulo: Martins Fontes, 1984.

CANCELA, Cristina Donza. Casamento e família em uma capital amazônica (Belém 18701920). Belém: Editora Açaí, 2011.

CARVALHO, José Murilo de. A construção da ordem: a elite imperial; Teatro das sombras: a política imperial. Rio de Janeiro: Civilização Brasileira, 2010.

CORRÊA, Mariza. Repensando a família patriarcal brasileira. In: ARANTES NETO, Antonio Augusto et al. Colcha de retalhos: estudos sobre a família no Brasil. 2. ed. Campinas: Editora da Unicamp, 1993. p. 15-45.

DUARTE, Regina Horta. O século XIX no Brasil: identidades conflituosas. In: CARVALHO, José Murilo de; NEVES, Lúcia Bastos P. das (orgs). Repensando o Brasil do Oitocentos. Rio de Janeiro: Civilização Brasileira, 2009. p. 563-570.

FARIA, Sheila de Castro. A colônia em movimento: fortuna e família no cotidiano colonial. Rio de Janeiro: Nova Fronteira, 1998.

FARIAS, William Gaia. A Revolta do Capim: camponeses envolvidos em disputas políticopartidárias no início da República. In: MOTTA, Márcia Menendes; ZARTH, Paulo Afonso. Formas de resistência camponesa: visibilidade, diversidade e conflitos ao longo da história. São Paulo: Editora UNESP, 2008. p. 305-328.

FARIAS, William Gaia. A construção da República no Pará (1886-1897). Belém: Açaí, 2016. FERLINI, Vera Lucia Amaral. Terra, trabalho e poder: o mundo dos engenhos no Nordeste colonial. São Paulo: Editora Brasiliense, 1988.

GRAHAM, Richard. Clientelismo e politica no Brasil do século XIX. Rio de Janeiro: Editora 
da UFRJ, 1997.

GRAMSCI. Antonio. Os intelectuais e a organizaçâo da cultura. Rio de Janeiro: Civilização Brasileira, 1968.

LACERDA, Franciane G. Cidade viva: Belém do Pará na virada do século XIX para o XX. In: LACERDA, Franciane G.; SARGES, Maria de Nazaré. Belém do Pará. História, cultura e cidade: para além dos 400 anos. Belém: Açaí, 2016. p. 145-164.

MARQUES, Fernando Luís Tavares. Arqueologia da arquitetura e os engenhos da maré no estuário amazônico. Anais do IV Seminário Ibero-Americano de Arquitetura e Documentação. Belo Horizonte, 2015. Disponível em: http://www.forumpatrimonio.com.br/arqdoc2015/ artigos/pdf/120.pdf. Acesso em: 2 mar. 2020.

MELLO, Maria Tereza Chaves de. A República consentida: cultura democrática e científica do final do Império. Rio de Janeiro: FGV, 2007.

MIRANDA, Vicente Chermont. Glossário paraense ou coleção de vocábulos à Amazônia e especialmente à Ilha do Marajó. 3. ed. Belém: Universidade Federal do Pará, 1968.

MIRANDA, Victorino Coutinho Chermont de Miranda. A família Chermont: memória histórica e genealógica. Rio de Janeiro: Eu \& Você Editora, 1982.

MESQUITA, Eni Samara de. O papel do agregado na regiāo de Itu (1780-1930). São Paulo: Coleção do Museu Paulista, 1977. p. 112-121.

MUAZE, Mariana de Aguiar Ferreira. Por uma micro-história da família. In: BESSONE, Tânia Maria; NEVES, Lúcia Maria Bastos P.; GUIMARÃES, Lúcia Maria P. (orgs). Elites, fronteiras e cultura do Império do Brasil. Rio de Janeiro: Contracapa, 2013. p. 13-32.

PAZ, Adalberto. Classe, cor e etnia nas legislaçôes de compulsão ao trabalho na Amazônia: do Diretório ao fim dos Corpos de Trabalhadores (1755-1859). Mundos do Trabalho, Florianópolis, v. 12, p. 1-28, maio 2020. Disponível em: https://periodicos.ufsc.br/index. php/mundosdotrabalho/article/view/1984-9222.2020.e72949. Acesso em: 2 maio 2020.

PICCININ, Adriana et. al. Introdução de búfalos no Brasil e sua produçâo leiteira. Revista Cientifica Eletrônica de Medicina Veterinária, ano IV, n. 8, p. 1-6, 2007.

SARGES, Maria de Nazaré. Belém: riquezas produzindo a Belle Époque. 2 ed. Belém: PakaTatu, 2010.

WEINSTAIN, Bárbara. A borracha na Amazônia: expansão e decadência (1850-1920). São Paulo: Hucitec/EDUSP, 1993.

VELLASCO, Ivan de Andrade. Clientelismo, ordem privada e Estado no Brasil oitocentista: notas para um debate. In: CARVALHO, José Murilo de; NEVES, Lúcia Bastos P. das (orgs). Repensando o Brasil do Oitocentos. Rio de Janeiro: Civilizaçăo Brasileira, 2009. p. 71-100. WILLIAMS, Raymond. O campo e a cidade: na história e na literatura. São Paulo: Companhia das Letras, 2011. 